\title{
Influence of tillage, cultivar, seed rate and planting geometry on wheat yield
}

\author{
Rajender Singh Chhokar*, Ramesh Kumar Sharma, Subhash Chander Gill and Raj Kumar \\ ICAR-Indian Institute of Wheat and Barley Research, Karnal, Haryana, India
}

\section{Article history}

Received: 28 March 2017

Revised : 02 April 2017

Accepted: 30 June 2017

\section{Citation}

Chhokar RS, RK Sharma, SC Gill and R Kumar. 2017. Influence of tillage, cultivar, seed rate and planting geometry on wheat yield. Journal of Wheat Research 9(1): 12-20.

doi.org/10.25174/2249-

$4065 / 2017 / 71641$

\section{*Corresponding author}

Email: Rajender.Chhokar@icar.gov.in

(C) Society for Advancement of Wheat and Barley Research

\begin{abstract}
Field experiments were conducted to improve the wheat yield through adjustments in seed rate, spacing and sowing method at Indian Institute of Wheat and Barley Research, Karnal, Haryana during Rabi seasons of 2008-09 to 2012-13. The results showed that by using the precision seed drilling, seed rate from present recommendations of $100 \mathrm{~kg} / \mathrm{ha}$ can be reduced to $75 \mathrm{~kg} / \mathrm{ha}$, however further reduction in seed rate caused yield reductions. If we translate $25 \%$ saving across the wheat growing area of India ( $30 \mathrm{mha}$ ) then we can have a huge saving of about $7.5 \times 10^{5}$ ton per year of wheat seed. The yield improved as row spacing was reduced from 22.5 to $15 \mathrm{~cm}$, although yield was not significantly different among $15,17.5$ and $20 \mathrm{~cm}$ row spacing. Among three varieties (PBW 550, PBW 502 and DBW 17) maximum yield was produced by PBW 550. Among three crop establishment methods viz. no till (NT), conventional till (CT) and bed planted wheat, the lowest yield was obtained in bed planted system, whereas NT and CT had similar yield levels. In 2 and 3 rows bed planted system, 3 rows yielded more compared to 2 row system. Yield improved with bidirectional (criss-cross) sowing $(1 / 2+1 / 2$ seed) compared to uni-directional sowing. The results of the present studies clearly indicate that wheat yield can be improved through right choice of cultivar, seed rate, spacing and crop establishment methods (Criss- cross sowing).
\end{abstract}

Key words: Bed planting, broadcast sowing, criss-cross sowing, no-till and wheat

\section{Introduction}

Crop yield depends on genotypes (genetic potential of a variety), environment (soil and climatic conditions) and management practices. Crop genotypes may vary in their growth and yield contributing factors (tillers $/ \mathrm{m}^{2}$, spike/ $\mathrm{m}^{2}$, grains/spike, grain weight). The appropriate combination of these yield attributes is needed for harvesting maximum productivity. Generally, among wheat yield attributes, the most significant contributor is spikes $/ \mathrm{m}^{2}$. Depending on the effective tillering of a cultivar, optimum earhead density can be achieved through seed rate adjustments. The varieties having high tillering can contribute higher yield at low seed rate and vice-versa.
Optimum planting geometry (plant population and their distribution) is a pre-requisite to realize the full genetic potential of a variety, which can be achieved through seed rate and spacing adjustments. Planting geometry affects light penetration in plant canopies, plants per unit area and micro environment in and around plant canopies. It should be in such a manner that it minimizes the intra-plant competition and maximizes resource utilization (space, solar radiation, nutrient and moisture) for higher yield. So, ideally, the plants should be arranged equidistantly from each other in the field, thereby equally sharing growth resources (Berry, 1967). Duncan (1971) also reported that crop 
productivity can be enhanced by varying the planting geometry for better light and $\mathrm{CO}_{2}$ utilization. Also, with altered plant geometry the decline in per plant yield is compensated by cumulative plant yields through adjustment in yield attributes (mainly the effective tillering) leading to maximum per unit area yield. The general recommendation for wheat in India is 20-22.5 $\mathrm{cm}$ row spacing with seed rate of $100 \mathrm{~kg} / \mathrm{ha}$ (considering 1000 grains weight as $38 \mathrm{~g}$ ).

There are contradictory reports regarding the role of row spacing and seed rate in wheat production. Numerous research workers from different regions have reported the benefits of narrow row spacing (Holliday, 1963; Sroskopf, 1967; Auld et al., 1983; Kemp et al., 1983; Roth et al., 1984; Frederick and Marshall, 1985; Joseph et al., 1985; Winter and Welch, 1987; Marshall and Ohm, 1987; Johnson et al., 1988; Freeze and Bacon, 1990; Tompkins et al., 1991; Solie et al., 1991; Marko, 1994; Sial et al., 2001; Arian et al., 2002; Chen et al., 2008) and increased seed rate (Teich et al., 1993; Arian et al., 2002). Some of the workers reported the benefit of narrow row spacing of as low as $9 \mathrm{~cm}$ (Tompkins et al. 1991) in wheat. Contrary to it, some workers (Lafond, 1994; Lafond and Derksen, 1996; Lafond and Gan, 1999; McLeod et al. 1996; Raj et al. 1992; Roy et al 1991; Sharma and Thakur (1990) observed no significant differences among row spacing and reported wider spacing $(25-30 \mathrm{~cm})$ as beneficial because it facilitate intercultivation for weed management and feasibility of inter cropping.

The crop row spacing also depends on the cultivars and growing conditions. Narrow spacing and higher seed rates are generally preferred under high productive environment to achieve maximum yield. Narrow spaced rows favor dwarf low tillering cultivars, whereas cultivars with high tillering rate performs better in wider rows. Wheat grown at $10 \mathrm{~cm}$ row spacing produced 0.4$0.8 \mathrm{t} /$ ha more grain than $20 \mathrm{~cm}$ rows spacing (Joseph $e t$ al. 1985; Johnson et al. 1988). When row spacing of soft red winter wheat was decreased from $17.8 \mathrm{~cm}$ to 12.7 $\mathrm{cm}$ in Pennsylvania, yield increased by 7.5\% (Roth et al. 1984) and by $8.2 \%$ (Frederick and Marshall 1985). Solie et al.(1991) observed improved wheat yields in weed (Cheat) free and weedy conditions when row spacing was reduced from 23 to $7.5 \mathrm{~cm}$. A predicted 14.2\% yield increase was observed as row spacing reduced to 7.5 $\mathrm{cm}$. They further stated that optimum row spacing for hard red winter wheat seeded at recommended seeding rates is projected to be $6.6 \mathrm{~cm}$.

Seeding rates alone did not influence grain yield much but suitable combination of seed rate and row spacing could increase grain yield of wheat (Marshall and Ohm, 1987). Roth et al. (1984) also recommended a cumulative response of narrow row spacing and increased plant density. Row spacing $(10$ and $20 \mathrm{~cm})$ at a constant (1.6, 3.2 , and $6.4 \mathrm{million}$ seed/ha seed rates) did not affect yield. With increasing seed rate there was an increase in yield mainly through more ear heads per unit area, which compensated for a decrease in seeds per head. Narrow rows also reduced the number of lamb'squarters and the overall weed count (Teich et al., 1993).

Method of sowing also affects crop productivity. Compared to broadcast sowing, line and cross sowings yield better (Arif et al., 1997; Dhiman et al., 1984). However, Ahuja et al., (1996) recorded $5.08 \mathrm{t} / \mathrm{ha}$ grain yield with broadcasting, while $4.75 \mathrm{t} /$ ha with sowing in $23 \mathrm{~cm}$ apart rows. Many workers have reported the wheat yield gain 4 to $18 \%$ with cross sowing as compared to unidirectional line sowing (Dhiman et al., 1984; Jadho and Nalamwar, 1993). Further, closer or cross sowings were also found effective in reducing the weed problem (Jadho and Nalamwar, 1993; Solie et al., 1991; Teich et al., 1993).

Keeping in view the importance of row spacing, seed rate and sowing method in realizing higher productivity, the present study was designed to the suitable crop geometry (seed rate and spacing), variety and sowing method for higher wheat grain yield under irrigated conditions of North Indian plains.

\section{Material and methods}

Field experiments were conducted to optimize wheat productivity through identification of suitable varieties, row spacing, seed rate, plant geometry and tillage options during winter seasons of 2008-09 to 2012-13 at ICAR-Indian Institute of Wheat and Barley Research (IIWBR), Karnal, Haryana, India. The soil was sandy loam in texture, alkaline, low to medium in organic carbon and phosphorus and high 
in available potash. The details of the experiments conducted are as under.

2.1 Effect of row spacing and varieties: An experiment involving four row spacing with three varieties was sown in two consecutive winter seasons of 2010-11 and 2011-12 in split plot design. The main plot consisted of 4 row spacing $(15,17.5,20$ and $22.5 \mathrm{~cm})$ with three wheat varieties (PBW 550, PBW 502 and DBW 17) as sub-plots and the treatment combinations were replicated thrice. The sowing was done using a standard 8-tyne precision seeder (Bhopal drill) with row to row spacing as per treatment using a seed rate of $100 \mathrm{~kg} / \mathrm{ha}$ (1000 grain weight as $38 \mathrm{~g}$ ). Each plot had two swath of drill (16 lines) with a plot length of 8 meters. Based on the area and grain weight of a variety, the adjusted weighed quality of seed was drilled using the Bhopal drill. The sowing was done on $17^{\text {th }}$ November, 2010 and $08^{\text {th }}$ November, 2011, during first and second crop season, respectively. The other package of practices were followed as per the recommendations.

2.2 Effect of row spacing and seed rate (crop geometry): In this experiment, row spacings $(15,17.5,20$ and 22.5 $\mathrm{cm})$ and seed rates $(50,75,100,125,150 \mathrm{~kg} / \mathrm{ha})$ were evaluated in an experiment conducted thrice in split plot design during two crop seasons of 2010-11 and 2011-12. The sowing of wheat cultivars PBW 550 and DPW 621-50 was done on $30^{\text {th }}$ November and $9^{\text {th }}$ December 2010 during first year and on $9^{\text {th }}$ December, 2011 during second crop season. The spacing was kept in main plot and sub plots were assigned with seed rate. During first experimentation, main plot had three row spacing $(15,17.5$ and $20 \mathrm{~cm})$ and subsequent repetition of experiments had four row spacings (15, $17.5,20$ and $22.5 \mathrm{~cm}$ ). The five seed rates were finally adjusted considering 1000 grain weight as $38 \mathrm{~g}$. The plot size consisted of two swath of a standard 8-tyne precision seeder (Bhopal drill) and sowing was done using desired seed quantity calculated based on area per swath in a plot depending on row spacing, seed rate and 1000 seed weight.

2.3 Effect of tillage crop establishment: Experiments were conducted to compare the different crop establishment options (no tillage, bed planting, conventional tillage having unidirectional line sowing and cross sowing) during 2008-09 to 2012-2013 crop seasons. In bed planting option (FIRBS-Furrow Irrigated Raised Bed System), the geometry consisted of 2 or 3 rows per bed in line sowing. To know the contribution of various rows in 3 row bed planted wheat, the individual rows were harvested and yield recorded. In another option of broadcast sowing, seeds were broadcasted after field preparation and beds were formed using bed planter. Bed planter machine prepares two beds at a time with top width of about $40 \mathrm{~cm}$ and furrows of about $30 \mathrm{~cm}$. In no tillage (NT), except no field preparation other agronomic management options were similar and sowing was done using zero till seed cum fertilizer drill. The sowing of Conventional Tillage (CT) and cross sowing (CS) was done using precision seed drill (Bhopal drill). In cross sowing, seeding was done with half seed in one direction and the other half as cross sowing over the first sowing.

The recommended dose of fertilizer in different experiments consisted of $150 \mathrm{~kg} \mathrm{~N}, 60 \mathrm{~kg} \mathrm{P}_{2} \mathrm{O}_{5}$ and 30 $\mathrm{kg} \mathrm{K}_{2} \mathrm{O} / \mathrm{ha}$. To meet $\mathrm{PK}$ requirements, NPK mixture (12:32:16) was used as basal application. The balance $\mathrm{N}$ was applied in the form of urea as top dressing in two splits just before first and second irrigation at around 20 and 40 days after sowing, respectively. Irrigations were applied using the check basin method in flat bed and in furrows for bed planting system. Recommended herbicides were used as per requirement in different experiments against broadleaf and grass weeds in wheat.

The observations were recorded on various yield and yield attributes. The effective tillers were counted about a fortnight before harvesting in one running meter at two places in each plot and converted to per meter square. The crop was manually harvested and threshing was done by small plot thresher and after recording the yield, a random sample was taken from each treatment to calculate 1000 grain weight (TGW). The grains/ earhead were worked out using the formula (yield, q/ ha $\times 10000) /\left(\right.$ earhead $\left./ \mathrm{m}^{2} \times \mathrm{TGW}, \mathrm{g}\right)$.

The data were subjected to analysis of variance (ANOVA) for determining the differences among the treatment means and when the $\mathrm{F}$ test was significant, means were compared with Fisher's protected least significant difference (LSD) test at 5\% level of significance. Based on the data of different field observations, average and \pm SEM were also worked out. Two tail "Paired 
t-test" was used for comparing the significance of two treatment means. The data were pooled where the results were similar in experimentation over the years.

\section{Results and discussion}

3.1 Effect of row spacing and varieties: During both the years of study, the varietal differences were significant for yield and yield attributes (Table 1). However, the effect of row spacing was significant for earhead density and grains/ earhead and non-significant for yield and 1000 grains weight. The row spacing effect was significant for yield on pooled analysis basis. The interaction effects were non-significant for yield and yield attributes. The narrow row spacing of 15 and $17.5 \mathrm{~cm}$ recorded numerically higher grain yield than the 20 and $22.5 \mathrm{~cm}$ row spacing during both the years. On pooled basis, narrow row spacing had significantly higher yield than the widest row spacing of $22.5 \mathrm{~cm}$. The mean yield recorded in 15 and $17.5 \mathrm{~cm}$ row spacing was 62.60 and $62.75 \mathrm{q} /$ ha during 2010-11 and 64.16 and $62.43 \mathrm{q} /$ ha during 2011-12, respectively. Whereas, the yield recorded with wider spacing of 20 and $22.5 \mathrm{~cm}$ was 61.88 and $59.44 \mathrm{q} /$ ha during first year and 61.73 and $61.32 \mathrm{q} /$ ha during second year of study, respectively. The better yield in narrow row spacing was mainly due to more tillers $/ \mathrm{m}^{2}$ in narrow row spacing as compared to wider row spacing. Based on pooled analysis, narrow spacing of $15.0 \mathrm{~cm}$ recorded significantly higher number of tillers $/ \mathrm{m}^{2}\left(491 / \mathrm{m}^{2}\right)$ than spacing of $20 \mathrm{~cm}$ $\left(464 / \mathrm{m}^{2}\right)$ and $22.5 \mathrm{~cm}\left(443 / \mathrm{m}^{2}\right)$. The more effective tillers under narrow row spacing at the same seeding rate are likely due to more uniform spatial distribution causing less in-row-plant-to-plant competition as compared with the wide row spacing (Auld et al., 1983), where plants are more concentrated in narrow bands with lesser space per plant. The mean wheat yield recorded with three varieties namely DBW 17, PBW 550 and PBW 502 was 60.96, 63.60 and 60.44 $\mathrm{q} /$ ha during first year and 57.91, 66.24 and $63.08 \mathrm{q} / \mathrm{ha}$ during second year of experimentation, respectively. On pooled basis, the significantly highest yield was of PBW 550 (64.92 q/ha). The better yield of cultivar PBW 550 was due to more grains/earhead although its tillers $/ \mathrm{m}^{2}$ were the lowest. This variety also had shorter vegetative span than other two varieties.
There are differential views of the researchers about row spacing as some are in favour of narrow row spacing to harness more yield (Johnson et al., 1988, Marshall and Ohm, 1987; Roth et al., 1984; Fredrick and Marshall, 1985; Holliday, 1963) and others in favour of wider rows because of ease in mechanical inter-culture and no yield penalty (Nazir et al., 1987; Roy et al., 1991; Ayaz et al., 1999; Lafond, 1994; Lafond and Derksen, 1996; Lafond and Gan, 1999; McLeod et al., 1996). Some studies in Saskatchewan, Canada, demonstrated no yield differences of spring and winter wheat at $10-\mathrm{cm}$ vs 30-cm row spacing comparison (Lafond, 1994; Lafond and Derksen, 1996; Lafond and Gan, 1999) and $18 \mathrm{~cm}$ vs $36 \mathrm{~cm}$ comparison (McLeod et al., 1996).

However, Roth et al. (1984) reported consistent yield increase in Pennsylvania with a narrow row spacing of $12.7 \mathrm{~cm}$ than recommended $17.8 \mathrm{~cm}$. Also, Fredrick and Marshall (1985) observed a significant yield increase of 6.0 to $13.2 \%$ with decreasing row spacing. Similarly, Holliday (1963) estimated increased wheat grain yield by $5-7 \%$ with narrower row spacing than the conventional $(18-23 \mathrm{~cm})$ spacing. Joseph et al. (1985) recorded 0.6 to $0.8 \mathrm{t} /$ ha higher grain yield in $10 \mathrm{~cm}$ over $20 \mathrm{~cm}$ row spacing and Marko (1994) reported $0.3 \mathrm{t} /$ ha more grain yield at a spacing of $6 \mathrm{~cm}$ over 15 cm. Ercoli and Masoni (1995) reported that grain yield decreased progressively with increase in row spacing, however yield was not affected by row orientations.

3.2 Effect of row spacing and seed rate: The field experiments were conducted to evaluate the effect of row spacing and seed rate on productivity of wheat cultivars (PBW 550 and DPW 621-50). The effect of row spacing was non-significant in both the varieties but the effect of seed rate was found significant (Table 2 ). The yield was significantly less at seed rate of 50 $\mathrm{kg} / \mathrm{ha}$ but seed rate of $75 \mathrm{~kg} / \mathrm{ha}$ and more had more or less similar grain yield in all the three experimentations during two consecutive years of study. Similarly, Samra and Dhillon (1993) observed non significant effect of seed rate varying from 75 to $125 \mathrm{~kg} / \mathrm{ha}$ in their studies involving wheat cultivars, seed rates $(75,90,105$ and $125 \mathrm{~kg} / \mathrm{ha}$ ) and $\mathrm{N}$ levels. Ciha (1993) also reported optimum grain yield at a seed rate of $75 \mathrm{~kg} / \mathrm{ha}$. While, Salazar et al., (1996) reported that seed rate can be reduced up to $5 \mathrm{~kg} /$ ha without reduction in grain yield 
as compared to seed rate of $150-200 \mathrm{~kg} / \mathrm{ha}$. In India, generally, a seed rate of $100 \mathrm{~kg} / \mathrm{ha}$ have been widely used (Singh and Singh, 1984).

Based on these results, the seed rate can be reduced by $25 \%$ for optimum wheat production. Extending the seed rate savings, by using precision seed drilling mechanism, across the wheat growing area of our country (30 mha), an enormous saving of about $750 \mathrm{x}$ $10^{6} \mathrm{~kg}$ seed /year can be made, if recommended seed rate of $100 \mathrm{~kg} / \mathrm{ha}$ is considered. However, the seed rate being used is still higher, especially broadcast sowing (125 kg/ha). For seed production with limited breeder seed availability, the seed rate can be reduced to $50 \%$ to cover more area so as to harvest higher quantity of seed.

The earlier findings (Chen et al., 2008; Sial et al., 2001; Nanaenko and Loktionor, 1993; Kumar et al., 1991; Tompkins et al ., 1991; Arian et al., 2002 ) have shown improved wheat grain yield with combinations of narrow row spacing and higher seed rates. Sial et al. (2001) observed improved wheat grain yield with combination of $15 \mathrm{~cm}$ narrow row spacing and higher seed rate of $150 \mathrm{~kg} / \mathrm{ha}$. Similarly, Nanaenko and
Loktionor (1993) also reported significantly higher grain yield at $7.5 \mathrm{~cm}$ row spacing with $150 \mathrm{~kg} / \mathrm{ha}$ seed rate than $15 \mathrm{~cm}$ row spacing and $100 \mathrm{~kg} / \mathrm{ha}$ seed rate. Kumar et al. (1991) reported increased grain yield particularly of long spike cultivars with higher seeding rates coupled with narrow row spacing while comparing the varietal performance having variable tillering and spike length at different seeding rates (100, 125 and 150 $\mathrm{kg} / \mathrm{ha}$ ) and row spacing $(15,18$ and $22.5 \mathrm{~cm})$. Xhomo (1989) obtained highest yield at a density of 600 plants/ $\mathrm{m}^{2}$. The greater grain yield with higher densities is due to greater number of spikes per unit area as the spike number is the main factor controlling wheat grain yield. However, sometimes lodging may be a problem particularly at high plant densities. Optimum plant density is of immense importance for higher yield as it helps in maximum utilization of the resources. However, it may vary depending upon the on genotypes and growing conditions. For late sown wheat, we have to increase the seed rate by $25 \%$ so as to compensate for yield decline due to lower tiller formation.

Table 1. Effect of row spacing and varieties on yield and yield attributes of wheat

\begin{tabular}{|c|c|c|c|c|c|c|c|c|c|c|c|c|}
\hline \multirow[t]{2}{*}{ Treatment } & \multicolumn{3}{|c|}{ Earhead $/ \mathrm{m}^{2}$} & \multicolumn{3}{|c|}{1000 grain weight $(\mathrm{g})$} & \multicolumn{3}{|c|}{ Grains/earhead } & \multicolumn{3}{|c|}{ Grain Yield (q/ha) } \\
\hline & $\begin{array}{c}2010- \\
11\end{array}$ & $\begin{array}{c}2011- \\
12\end{array}$ & Pooled & $\begin{array}{c}\text { 2010- } \\
11\end{array}$ & $\begin{array}{c}2011- \\
12 \\
\end{array}$ & Pooled & $\begin{array}{c}2010- \\
11\end{array}$ & $\begin{array}{c}2011- \\
12\end{array}$ & Pooled & 2010-11 & $\begin{array}{c}2011- \\
12\end{array}$ & Pooled \\
\hline \multicolumn{13}{|l|}{ Spacing $(\mathrm{cm})$} \\
\hline 15.0 & 527 & 456 & 491 & 40.7 & 44.8 & 42.8 & 29.6 & 31.7 & 30.7 & 62.60 & 64.16 & 63.38 \\
\hline 17.5 & 513 & 431 & 472 & 40.8 & 44.8 & 42.8 & 30.7 & 32.5 & 31.6 & 62.75 & 62.43 & 62.59 \\
\hline 20.0 & 503 & 424 & 464 & 40.1 & 44.7 & 42.4 & 31.5 & 32.9 & 32.2 & 61.88 & 61.73 & 61.80 \\
\hline 22.5 & 465 & 421 & 443 & 40.2 & 44.5 & 42.4 & 32.5 & 33.1 & 32.8 & 59.44 & 61.32 & 60.38 \\
\hline $\operatorname{LSD}(p=0.05)$ & 34.8 & N.S. & 26.4 & NS & NS & NS & 0.96 & 1.08 & NS & NS & NS & 1.95 \\
\hline \multicolumn{13}{|l|}{ Varieties } \\
\hline DBW17 & 586 & 459 & 522 & 39.6 & 43.2 & 41.4 & 26.4 & 29.4 & 27.9 & 60.96 & 57.91 & 59.43 \\
\hline PBW 550 & 434 & 411 & 422 & 39.3 & 44.1 & 41.7 & 37.5 & 36.7 & 37.1 & 63.60 & 66.24 & 64.92 \\
\hline PBW 502 & 487 & 429 & 458 & 42.5 & 46.9 & 44.7 & 29.4 & 31.6 & 30.5 & 60.44 & 63.08 & 61.76 \\
\hline $\operatorname{LSD}(\mathrm{p}=0.05)$ & 30.3 & 24.2 & 16.7 & 0.61 & 0.64 & 0.54 & 1. 70 & 1.85 & 1.15 & 1.67 & 1.52 & 0.99 \\
\hline
\end{tabular}


Table 2. Effect of row spacing and seed rate on wheat yield during 2010-11 and 2011-12

\begin{tabular}{|c|c|c|c|c|}
\hline \multirow[t]{3}{*}{ Treatments } & \multicolumn{4}{|c|}{ Grain Yield (q/ha) } \\
\hline & \multicolumn{2}{|c|}{$2010-11$} & \multirow{2}{*}{$\begin{array}{c}\text { 2011-12 } \\
\text { PBW } \\
550 \\
\text { (Sown } \\
\text { on 9th } \\
\text { Dec) }\end{array}$} & \multirow[t]{2}{*}{ Pooled } \\
\hline & $\begin{array}{c}\text { Set } 1 \\
\text { (PBW } \\
550 \text { sown } \\
\text { on 30th } \\
\text { Nov.) }\end{array}$ & $\begin{array}{c}\text { Set } 2 \\
\text { (DPW } \\
621-50 \\
\text { Sown on } \\
\text { 9th Dec) }\end{array}$ & & \\
\hline \multicolumn{5}{|l|}{ Spacing $(\mathrm{cm})$} \\
\hline 15.0 & 56.03 & 49.62 & 57.52 & 54.39 \\
\hline 17.5 & 55.67 & 48.35 & 57.56 & 53.86 \\
\hline 20.0 & 55.28 & 47.71 & 56.00 & 53.00 \\
\hline 22.5 & - & 47.52 & 55.18 & 51.35 \\
\hline $\operatorname{LSD}(p=0.05)$ & NS & NS & NS & \\
\hline \multicolumn{5}{|c|}{ Seed rate $(\mathrm{kg} / \mathrm{ha})$} \\
\hline 50 & 54.32 & 45.53 & 54.88 & 51.58 \\
\hline 75 & 55.97 & 48.11 & 57.01 & 53.70 \\
\hline 100 & 56.07 & 49.35 & 56.77 & 54.06 \\
\hline 125 & 55.81 & 49.17 & 57.32 & 54.10 \\
\hline 150 & 56.13 & 49.35 & 56.85 & 54.11 \\
\hline $\operatorname{LSD}(p=0.05)$ & 1.28 & 1.67 & 1.52 & - \\
\hline
\end{tabular}

3.3 Effect of tillage crop establishment (TCE): Different TCE were evaluated for 3-4 years with different wheat varieties and as the varietal performance was similar so, tillage wise data across varieties were pooled and presented in Figures 1-4. The perusal of data revealed no significant difference between CT (52.3 q/ha) and NT (51.7 q/ha) wheat yield (Fig. 1). However, NT has an advantage of reduced cost of cultivation/production due to reduction in tillage cost. So, wheat can be grown successfully under NT as cost effective technology. In comparison to CT $(52.3 \mathrm{q} / \mathrm{ha})$ and NT $(51.7 \mathrm{q} / \mathrm{ha})$, FIRBS (47.1 q/ha) recorded 4.6-5.2 q/ha lower yield. Although, FIRBS yielded lesser, yet, it has an advantage of water saving and system's diversification (Jat $e t$ al ., 2006). Some of the researchers have reported similar or better yield under bed planting system (Jat et al., 2006). This difference might be due to differences in varietal performance and agro climatic conditions. So there is a need to breed high tillering suitable genotypes for bed planting system.

In bed planting system also, different geometries involving FIRBS line sowing in 2 rows (2R) and 3 rows (3R) and broadcast sowing were evaluated (Fig. 2 and $3)$. Between $2 R$ and $3 R, 3 R$ had slight yield advantage than $2 \mathrm{R}$ and showed significance at $\mathrm{P}=0.10$ (Fig. 2). Whereas over $3 \mathrm{R}$, broadcast sown wheat had shown numeric yield advantage (Fig. 3). The better yield in broadcast sowing was due to more uniform distribution of seeds over large area because in line sowing only top of bed is covered but in broadcast sowing, sides of the beds are also covered with plant stand thus using more space. Although, the yield of $2 \mathrm{R}$ system was slightly lower to $3 \mathrm{R}$ but we can harness the added advantage of $2 R$ system of having the possibility of mechanized interculture as well as fertilizer placement by selecting suitable narrow wheel tractors. Moreover, there is a need to integrate suitable genotypes along with proper sowing time for the system. Early and normal sowing can give better yield in bed planted system compared to late seeding as narrow spacing is required for late sown wheat and in bed planting only 2-3 rows are grown in $70 \mathrm{~cm}$ (Centre of furrow to centre of furrow). However, this system of seeding can help in advancing the seeding time by avoiding the pre seeding irrigation after harvest of previous crop. Since, just after seeding in dry soil, irrigation can be applied for proper germination and crop establishment. Thus, besides reducing the turnaround time it will also help in saving of water. Moreover, the bed planted system has an additional advantage of diversification as there is a possibility to grow additional crop in furrows as intercrop or relay crop thus making the system more profitable. Further, by converting the beds into permanent beds with suitable cropping system will make this crop establishment system more economical.

In three row sowing, the wheat grain yield of individual row was calculated (Fig.4) and based on that the contribution of the side rows and the middle row on the total wheat productivity of 3 rows per bed was estimated for two growing seasons. It was found that centre row had lower yield than side rows/border rows. The contribution of middle row was $27.6 \%$ as compared to $72.4(37.3+35.1) \%$ by two side rows (Northern + Southern). This difference was due to the border effect as more space and other resources were available for side rows. As compared to unidirectional sowing, bidirectional or cross sowing (CS) i.e. $1 / 2$ seed rate in one direction and rest $1 / 2$ cross sown over the first had shown yield advantage (Fig. 5). About $2.4 \%$ higher yield was recorded with CS $(51.6 \mathrm{q} / \mathrm{ha})$ over CT unidirectional (50.4 q/ha) sowing. Dhiman et al. (1984) also reported advantage of cross sowing over unidirectional sowing.

As far as cross and narrow row space sowings are concerned, we have to improve the drilling mechanism by replacing the tyne drilling with double disc drilling. Such alteration will allow very less soil disturbance during drilling and will ensure proper crop stand and ultimately the yield advantage. Further experiments are needed with varying the spacing using the disc type drilling mechanism. 


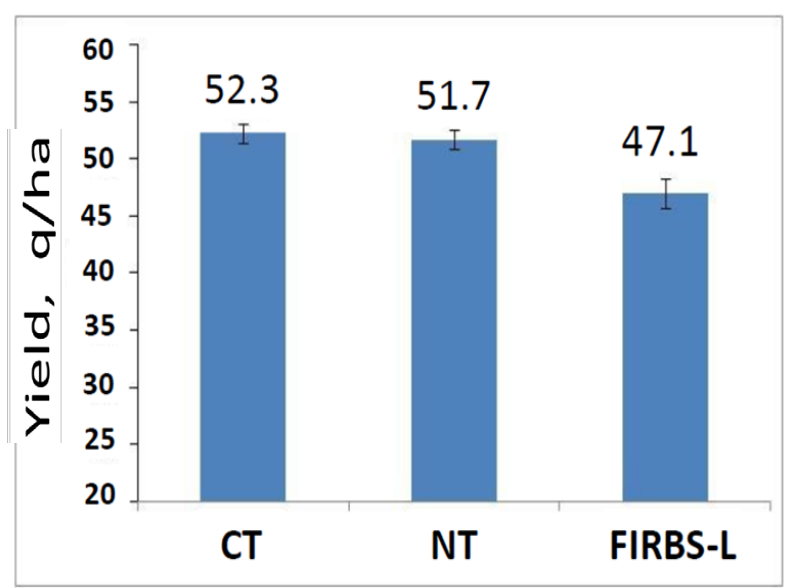

Fig. 1 Performance of wheat under different tillage systems $(\mathrm{CT}=$ conventional tillage, $\mathrm{NT}=$ notillage and FIRBS-L= Furrow irrigated raised bed system-line sowing). Vertical bars represent \pm SEM (average of 15 field observations).

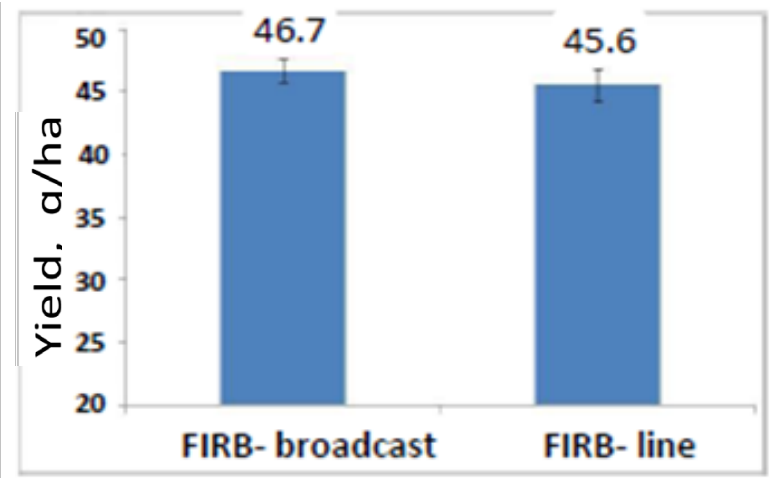

Fig 3. Performance of broadcast and line seeded bed planted systems. (average of 6 field observations). Vertical bars represent \pm SEM. Means are not significantly different at $\mathrm{P}=0.10$ using two tailed "Paired t test"

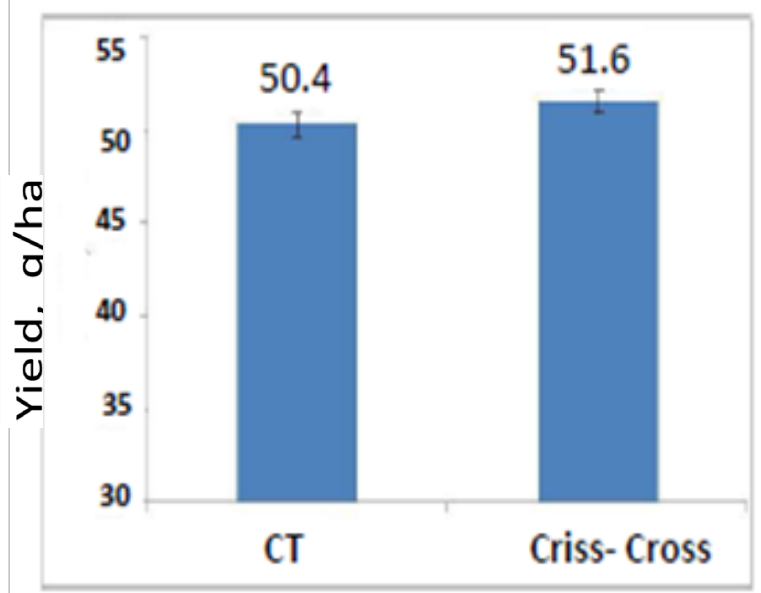

Fig. 5. Performance of wheat under conventional tillage (CT) and cross sowing methods. (average of 8 field observations). Vertical bars represent \pm SEM. Means are significantly different at $\mathrm{P}=0.10$ using two tailed "Paired t test".

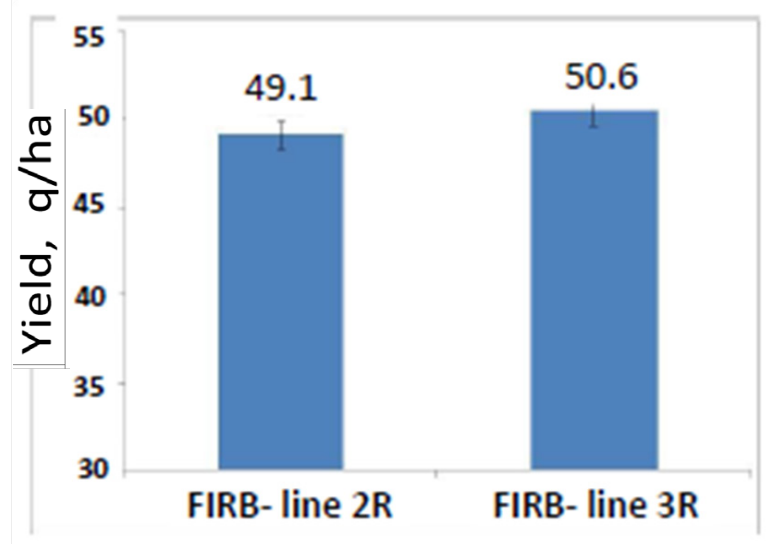

Fig 2. Performance of wheat under 2 row and 3 row bed planted orientation geometry. (average of 7 field observations). Vertical bars represent \pm SEM. Means are significantly different at $\mathrm{P}=0.10 \mathrm{using}$ two tailed "Paired t test".

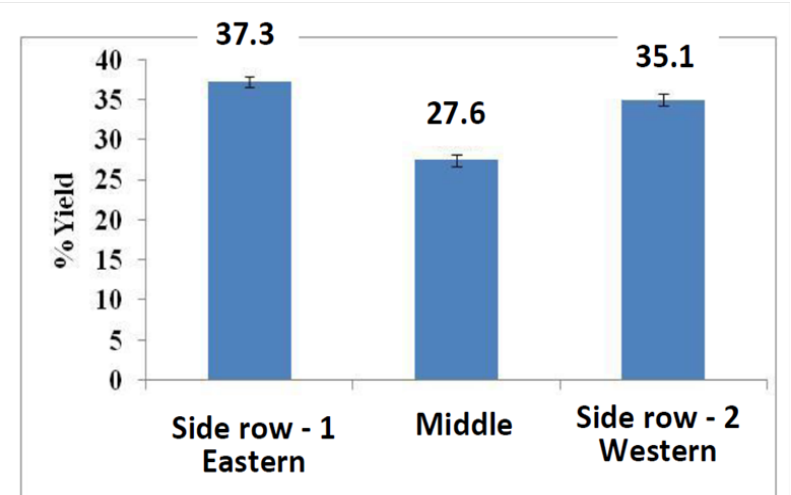

Fig. 4 Grain yield contribution (\%) of individual row in 3-R bed planting systems sown in north-south direction (average of 15 field observations). Vertical bars represent \pm SEM

Agronomic practices must aim at maximizing the capturing and utilization of plant growth resources. Narrow row spacing or cross sowing configurations with optimum plant density can help in early ground coverage and better resource utilization such as increased light capture by canopy than wider rows and lesser plant density. Based on this study, for improving wheat yield a closer spacing $(15-17.5 \mathrm{~cm})$ or cross sowing should be adopted. For cost saving NT wheat production should be adopted. We can also save (25\%) on account of the seed by using $75 \mathrm{~kg} / \mathrm{ha}$ seed rate by adopting precision drilling. For this, the fluted seed and fertilizer drilling mechanism should be replaced with the horizontal inclined plate drilling mechanism in seed-cum-fertilizer drills. Further, there is a need to 
identify or breed cultivars having bolder grains and more grains per earhead and which are also capable of maintaining these characters at high plant density with narrow spacing so as to harness more wheat grain yield.

\section{References}

1. Ahuja KN, RB Lal and A Kumar. 1996. Effect of seed rate, date and method of sowing on growth and yield of wheat. Annals of Agricultural Research 17 (2): 190-192.

2. Andrade FH, P Calvino, A Cirilo and P Barbieri. 2002. Yield responses to narrow rows depend on increased radiation interception. Agronomy Journal 94: 975-980.

3. Arif M, J Tahir, M Akram, M Aslam and TH Chaudhry. 1997. Effect of seed rates and drilling techniques on wheat yield. Journal of Agricultural Research 35: 303-308.

4. Arian MA, MA Sial and MA Javed. 2002. Influence of different seeding rates and row spacings on yield contributing traits in wheat. Pakistan Journal of Seed Technolgy 1(1): 1-6.

5. Auld BA, DR Kemp and RW Medd. 1983. The influence of spatial arrangement on grain yield of wheat. Australian Journal of Agricultural Research 34:99-108.

6. Ayaz S, P Shah, HM Sharif and I Ali. 1999. Yield, yield components and other important agronomic traits of wheat as affected by seed rate and planting geometry. Sarhad Journal of Agriculture 15 (4): 255-262

7. Berry, G. 1967. A mathematical model relating plant yield with arrangement for regularly spaced crops. Biometrics 23: 505-515.

8. Chen C, K Neill, D Wichman and M Westcott. 2008. Hard red spring wheat response to row spacing, seeding rate and nitrogen. Agronomy Journal 100:12961302.

9. Ciha AJ. 1993. Seeding rate and seeding date effects on spacing seeded small grain cultivars. Agronomy Journal 6: 795-798.

10. Dhiman SD, DN Sharma and MS Kairon. 1984. Cross sowing of wheat, beneficial technique. Haryana Agricultural University Journal of Research 14: 460-464.
11. Duncan WG. 1971. Leaf angle, leaf area and canopy photosynthesis. Crop Science 11: 482-485.

12. Ercoli L and A Masoni. 1995. Effects of row spacing and orientation on yield and yield components of winter wheat. Agricoltura Mediterranea 125: 215-221.

13. Frederick JR and HG Marshall. 1985. Grain yield and yield components of soft red winter wheat as affected by management practices. Agronomy Journal 77: 495-499.

14. Freeze DM and RK Bacon. 1990. Row spacing and seed-rate effects on wheat yields in the mid-south. Journal of Production Agriculture 3: 345-348.

15. Holliday R. 1963. The effect of row width on the yield of cereals. Field Crop Abstracts 16: 71-81.

16. Jadho SL and RU Nalamwar. 1993. Response of wheat (Triticum aestivum L.) genotypes to planting methods and manual weeding. Indian Journal of Agronomy 38: 382-385.

17. Jat ML, S Singh, HK Rai, RS Chhokar, SK Sharma and RK Gupta. 2006. Furrow irrigated raised bed planting techniques for diversification of rice-wheat cropping system in Indo Gangetic plains. JAICAF (Japan Association for International Collaboration of Agriculture and Forestry) 28 (1): 25-42.

18. Johnson JW, WL Hargrove, and RB Moss. 1988. Optimizing row spacing and seeding rate for soft red winter wheat. Agronomy Journal 80:164-166.

19. Joseph KDSM, MM Alley, DE Brann and WD Gravelle. 1985. Row spacing and seeding rate effects on yield and yield components of red winter wheat. Agronomy Journal 77: 211-214.

20. Kemp DR, BA Auld and RW Medd. 1983. Does optimizing plant arrangements reduce inference or improve the utilization of space? Agricultural System 12: 31-36.

21. Kumar A, AK Sinha, BP Sinha, KMP Singh and SS Thakur.1991. Response of wheat genotypes to seed rate and row spacing. Indian Journal of Agronomy 36: 78-82.

22. Lafond GP. 1994. Effects of row spacing, seeding rate and nitrogen on yield of barley and wheat under zero-till management. Canadian Journal of Plant Science 74: 703-711. 
23. Lafond GP, and DA Derksen. 1996. Row spacing and seeding rate effects in wheat and barley under a conventional fallow management system. Canadian Journal of Plant Science 76: 791-793.

24. Lafond GP and YT Gan. 1999. Row spacing and seeding rate studies in no-till winter wheat for the Northern Great Plains. Journal of Production Agriculture 12: 624-629.

25. Marko F. 1994. Effects of row spacing and seed rates on grain yield and properties of winter wheat seed. Rostlinna Vyroba 40: 431-438.

26. Marshall GC and HW Ohm. 1987. Yield responses of 16 winter wheat cultivars to row spacing and seeding rate. Agronomy Journal 79:1027-1030.

27. McLeod JG, CA Campbell, Y Gan, FB Dyck and CL Vera. 1996. Seeding depth, rate and row spacing for winter wheat grown on stubble and chemical fallow in the semiarid prairies. Canadian Journal of Plant Science 76: 207-214.

28. Nazir SM, A Hussain, G Ali and RH Shah. 1987. Conventional versus new geometry of planting wheat. Pakistan Journal of Agricultural Research 8(2): 125-129.

29. Nanaenko AK and GG Loktionor. 1983. Wheat yields in relation to sowing rate and stand evenness. Field Crop Abstracts 46(1): 2.

30. Raj S, D Singh and VU Rao. 1992. Effect of date of sowing and row spacing on the yield of wheat (Triticum aestivum L.). Crop Research (Hisar) 5(2): 199-206.

31. Roth GW, HG Marshall, OE Hatley and RR Hill Jr. 1984. Effect of management practices on grain yield, test weight and lodging of soft red winter wheat. Agronomy Journal 76: 379-383.

32. Roy SK, M Zaman and MS Zaman.1991. Effect of planting geometry and nitrogen application on the growth and yield of wheat. Indian Journal of Agronomy 36(Supp): 33-37.

33. Salazar GM, RO Moreno, GR Salazar and ML Carillo. 1996. Wheat production as affected by seeding rate $\mathrm{x}$ fertilization interaction. Cereal Research Communication 24: 231-237.
34. Samra IS and SS Dhillon. 1993. Effect of seed rate and nitrogen level on new genotypes (PBW 154 and PBW 222) of wheat. Indian Journal of Agronomy 38: $111-112$

35. Sharma RR and RC Thakur. 1990. Effects of seed rates, row spacing and soil moisture conservation practices on rainfed wheat (Triticum aestivum L.). Himachal Journal of Agricultural Research 16:1-5.

36. Sial MA, MA Arain, MA Javed and NA Nizamani. 2001. Response of wheat genotypes on yield and yield components with changing plant population densities. Pakistan Journal of Botany 33/Special issue): 797-800.

37. Singh H and R Singh. 1984. Effect of nitrogen and seed rates on wheat. Indian Journal of Agronomy 29: 129-130.

38. Solie JB, SG Solomon, KP Self, TF Peeper and JA Koscelny. 1991. Reduced row spacing for improved wheat yields in weed-free and weed infested fields. Transactions of the ASAE 34:1654-1660.

39. Sroskopf NC. 1967. Yield performance of uprightleaved selections of winter wheat in narrow row spacings. Canadian Journal of Plant Science 47: 597-601.

40. Teich AH, A Smid, T Welacky, and A Hamill. 1993. Row-spacing and seed-rate effects on winter wheat in Ontario. Canadian Journal of Plant Science 73: 31-35.

41. Tompkins, DK, GE Hultgreen, AT Wright and DB Fowler. 1991. Seed rate and row spacing of no-till winter wheat. Agronomy Journal 83: 684-689.

42. Winter SR and AD Welch. 1987. Tall and semi dwarf wheat response to dry land planting systems. Agronomy Journal 79: 641-645.

43. Xhomo A. 1989. The influence of plant density and nitrogen fertilizer on soft wheat cultivars. Field Crop Abstracts 45 (10): 852. 